\title{
PRODUCT OPTIMIZATION BY SCHEDULING FORMULATION \& OPTIMAL STORAGE STRATEGY FOR MULTIPRODUCT BATCH PLANTS
}

\author{
Anand P. Dhanwani ${ }^{1}$, Srinivasarao Meka ${ }^{2}$ \\ ${ }^{1}$ Associate Professor, Department of Chemical Engineering, Faculty of Technology, Dharmsinh Desai University, \\ Nadiad, Gujarat: India \\ ${ }^{2}$ Professor, Department of Chemical Engineering, Faculty of Technology, Dharmsinh Desai University, Nadiad,
} Gujarat: India

\begin{abstract}
This contribution involves the formulation that addresses the minimization of both fresh water intake and waste water generation simultaneously. It optimizes the product and reactor utilization. The production optimization for this problem is based on batch product scheduling of MINLP formulation using commercial solver GAMS 24.1.1. The main objective is to enhance the profitability, minimizing waste generation and reducing fresh water intake. This case study shows that the number of batches within the same source of available resources can be increased by $12.24 \%$ and the profitability can be increased to $13.36 \%$. On the other hand waste generation is reduced to almost $33 \%$ because of recycle and re-use opportunities. This suggests that by optimizing production, fresh water intake and waste water generation in the same scheduling formulation will minimize the operating cost and reduce the environmental impact significantly. The comparative study has been considered whether to have individual tanks of low and high COD nearer to each reactor or to have two centralized tanks, one for each low and high COD. The results of same have shown that the centralized (bigger) tanks occupies significant low space and they are highly economical. The efficacy of the results presented are demonstrated by taking a case study of pharmaceutical industry located in GIDC Vadodara, India.
\end{abstract}

Keywords: Wastewater minimization, Scheduling, Fresh water intake, Holding tank Multiproduct batch plant $* * *$

\section{INTRODUCTION}

Batch plants are getting serious attention because of their suitability and sustainability for the production of small lots and value added products. More than that their flexibility allows them to produce variety of products by sharing the same sort of equipments [1]. Various products of polymer, pharmaceutical, food and beverages and specialty chemicals are manufactured through batch process as their demand is highly influenced by seasonal variation, changing scenario of market [2]. There is no doubt about the flexibility of batch plant but they have lot of challenges towards design, synthesis and operation in comparison with continuous plants. The profitability[1][2] of these batch plants is highly dependent on the ways they synthesize, design and optimally operated so the modeling, optimum design of batch plant operation is important part of getting economic benefit[1][2]. Significant cost savings can be achieved or production efficiency can be increased through appropriate production optimization and scheduling for a production plant[2]. Because of the growing awareness in the society for the environment, increasing scarcity of water and stringent pollution norms, there is a huge opportunity for the application of recycling technology[3]. The fresh water and effluent treatment cost is moving significantly higher due to environmental sustainability. It has motivated the process industry to find new and alternate ways to curtail the fresh water consumption and waste water generation[4]. Serious measures are considered by process plants towards the minimization of fresh water consumption via creating recycle and reuse opportunity within the plant[5].The production cost can be significantly reduced by minimizing the effluent generation which ensures sustainable growth in the business environment[6][7]. So special effort is required to develop methodology that offers opportunity for both production optimization and waste water minimization. This effort would definitely provide the better production schedule which improves efficiency of batch plant when it is compared with optimization of water separatel.

\section{CASE STUDY OF PHARMACEUTICAL PLANT}

In this problem, an industrial case study represents a mathematical technique that addresses optimization of water usage, while simultaneously optimizing the no. of batches to be produced and profitability.

\section{PROBLEM STATEMENT}

This problem has been taken from Gujarat based pharmaceutical unit for single plant having 12 products and 12 reactors. Here batch size, batch length of each product, available time of each reactor, minimum no. of batches to be produced for each product is available. The reactor washing data after each batch of individual product is also available. 
Table--1: Industrial Data: Complete data of 12 Products and Time Cycle for the same

\begin{tabular}{|l|l|l|l|l|l|l|}
\hline $\begin{array}{l}\text { Compound along } \\
\text { with stage }\end{array}$ & $\begin{array}{l}\text { Existing } \\
\text { batches }\end{array}$ & Batch size(kg) & $\begin{array}{l}\text { Quantity of } \\
\text { product } \\
(\mathrm{kg})\end{array}$ & $\begin{array}{l}\text { Batch cycle } \\
\text { time (hrs) }\end{array}$ & $\begin{array}{l}\text { Total production } \\
\text { time(hrs) }\end{array}$ & $\begin{array}{l}\text { Profit /batch } \\
\text { (Rs.) }\end{array}$ \\
\hline a & 38 & 230 & 9430 & 180 & 7380 & 23000 \\
\hline $\mathrm{b}$ & 54 & 75 & 4500 & 120 & 7200 & 30000 \\
\hline $\mathrm{c}$ & 4 & 9 & 36 & 70 & 280 & 45000 \\
\hline $\mathrm{d}$ & 9 & 14 & 140 & 30 & 300 & 35000 \\
\hline $\mathrm{e}$ & 9 & 20 & 200 & 100 & 1000 & 40000 \\
\hline $\mathrm{f}$ & 11 & 9 & 108 & 20 & 240 & 45000 \\
\hline $\mathrm{g}$ & 3 & 60 & 180 & 50 & 150 & 60000 \\
\hline $\mathrm{h}$ & 4 & 30 & 150 & 60 & 300 & 60000 \\
\hline $\mathrm{i}$ & 5 & 35 & 175 & 70 & 350 & 70000 \\
\hline $\mathrm{j}$ & 4 & 15 & 60 & 20 & 80 & 45000 \\
\hline $\mathrm{k}$ & 2 & 140 & 280 & 75 & 150 & 42000 \\
\hline $\mathrm{l}$ & 4 & 3 & 12 & 250 & 1000 & 60000 \\
\hline Total & $\mathbf{1 4 7}$ & & & & \\
\hline
\end{tabular}

Table- 2: Industrial Data: Complete data of 12 Reactors and Time Cycle for the same

\begin{tabular}{|l|l|l|l|l|l|l|l|l|l|l|l|l|l|l|}
\hline $\begin{array}{l}\text { Reacto } \\
\text { rs }\end{array}$ & $\mathrm{a}$ & $\mathrm{b}$ & $\mathrm{c}$ & $\mathrm{d}$ & $\mathrm{e}$ & $\mathrm{f}$ & $\mathrm{g}$ & $\mathrm{h}$ & $\mathrm{i}$ & $\mathrm{j}$ & $\mathrm{k}$ & $\mathrm{l}$ & $\begin{array}{l}\text { Total } \\
\text { Time } \\
\text { (hours) }\end{array}$ & $\begin{array}{l}\text { Net } \\
\text { available } \\
\text { time } \\
\text { (hours) }\end{array}$ \\
\hline R-01 & & & 980 & & & & & & & & & & 1188 & 980 \\
\hline R-02 & & 1800 & & & & & & & & & & & 1992 & 1800 \\
\hline R-03 & 900 & 1080 & & & & & & & & & & & 2196 & 1980 \\
\hline R-04 & 540 & 360 & & & & & 400 & & & & & & 1535 & 1303 \\
\hline R-05 & $\begin{array}{l}108 \\
0\end{array}$ & 360 & & & & & 250 & & & & & & 1926 & 1690 \\
\hline R-06 & $\begin{array}{l}126 \\
0\end{array}$ & 240 & & & & & 100 & & & & & & 1808 & 1600 \\
\hline R-07 & $\begin{array}{l}126 \\
0\end{array}$ & 240 & & & & & 50 & & & & & & 1742 & 1550 \\
\hline R-08 & 1680 & & 180 & & 20 & & & & & & & 2153 & 1880 \\
\hline R-09 & 1440 & & 180 & & 120 & & & & & & & 2043 & 1740 \\
\hline R-10 & $\begin{array}{l}126 \\
0\end{array}$ & & & & & 60 & & & & & & & 1524 & 1320 \\
\hline R-11 & $\begin{array}{l}162 \\
0\end{array}$ & & & & & & & & & & & & 1788 & 1620 \\
\hline R-12 & $\begin{array}{l}162 \\
0\end{array}$ & & & & & & & & & & & & 1788 & 1620 \\
\hline
\end{tabular}

Table- 3: Actual fresh water required (liters) through washing.

\begin{tabular}{|c|c|c|c|c|c|c|c|c|c|c|c|c|c|}
\hline $\begin{array}{l}\text { React } \\
\text { ors }\end{array}$ & $\begin{array}{l}\text { Size of } \\
\text { Reacto } \\
\mathrm{r} \text { in } \\
{[\mathrm{Lit}]}\end{array}$ & $\mathrm{a}$ & $\mathrm{b}$ & c & d & $\mathrm{e}$ & $\mathrm{F}$ & G & $\mathrm{h}$ & $\mathrm{i}$ & $\mathrm{j}$ & $\mathrm{k}$ & 1 \\
\hline $\begin{array}{l}\text { No of } \\
\text { Require }\end{array}$ & d Washes & 7 & 5 & 3 & 3 & 3 & 3 & 5 & 4 & 4 & 3 & 5 & 3 \\
\hline R-01 & 750 & 5250 & 3750 & 2250 & 2250 & 2250 & 2250 & 3750 & 3000 & 3000 & 2250 & 3750 & 2250 \\
\hline R-02 & 1200 & 8400 & 6000 & 3600 & 3600 & 3600 & 3600 & 6000 & 4800 & 4800 & 3600 & 6000 & 3600 \\
\hline R-03 & 2000 & 14000 & 10000 & 6000 & 6000 & 6000 & 6000 & $\begin{array}{l}1000 \\
0\end{array}$ & 8000 & 8000 & 6000 & 10000 & 6000 \\
\hline
\end{tabular}




\begin{tabular}{|l|l|l|l|l|l|l|l|l|l|l|l|l|l|} 
R-04 & 2500 & 17500 & 12500 & 7500 & 7500 & 7500 & 7500 & $\begin{array}{l}1250 \\
0\end{array}$ & $\begin{array}{l}1000 \\
0\end{array}$ & 10000 & 7500 & 12500 & 7500 \\
\hline R-05 & 3000 & 21000 & 15000 & 9000 & 9000 & 9000 & 9000 & $\begin{array}{l}1500 \\
0\end{array}$ & $\begin{array}{l}1200 \\
0\end{array}$ & 12000 & 9000 & 15000 & 9000 \\
\hline R-06 & 3000 & 21000 & 15000 & 9000 & 9000 & 9000 & 9000 & $\begin{array}{l}1500 \\
0\end{array}$ & $\begin{array}{l}1200 \\
0\end{array}$ & 12000 & 9000 & 15000 & 9000 \\
\hline R-07 & 2000 & 14000 & 10000 & 6000 & 6000 & 6000 & 6000 & $\begin{array}{l}1000 \\
0\end{array}$ & 8000 & 8000 & 6000 & 10000 & 6000 \\
\hline R-08 & 630 & 4410 & 3150 & 1890 & 1890 & 1890 & 1890 & 3150 & 2520 & 2520 & 1890 & 3150 & 1890 \\
\hline R-09 & 1000 & 7000 & 5000 & 3000 & 3000 & 3000 & 3000 & 5000 & 4000 & 4000 & 3000 & 5000 & 3000 \\
\hline R-10 & 2000 & 14000 & 10000 & 6000 & 6000 & 6000 & 6000 & $\begin{array}{l}1000 \\
0\end{array}$ & 8000 & 8000 & 6000 & 10000 & 6000 \\
\hline R-11 & 2500 & 17500 & 12500 & 7500 & 7500 & 7500 & 7500 & $\begin{array}{l}1250 \\
0\end{array}$ & $\begin{array}{l}1000 \\
0\end{array}$ & 10000 & 7500 & 12500 & 7500 \\
\hline R-12 & 3000 & 21000 & 15000 & 9000 & 9000 & 9000 & 9000 & $\begin{array}{l}1500 \\
0\end{array}$ & $\begin{array}{l}1200 \\
0\end{array}$ & 12000 & 9000 & 15000 & 9000 \\
\hline
\end{tabular}

Table- 4: High COD waste water Produced Through Washing

\begin{tabular}{|l|l|l|l|l|l|l|l|l|l|l|l|l|l|}
\hline $\begin{array}{l}\text { React } \\
\text { ors }\end{array}$ & $\begin{array}{l}\text { Size of } \\
\text { in } \\
\text { [Liters] }\end{array}$ \\
$\begin{array}{l}\text { No of Washes } \\
\text { Required }\end{array}$ & a & b & c & d & e & f & g & h & i & j & K & 1 \\
\hline R-01 & 750 & 3000 & 2250 & 1500 & 1500 & 1500 & 1500 & 2250 & 1500 & 1500 & 1500 & 2250 & 1500 \\
\hline R-02 & 1200 & 4800 & 3600 & 2400 & 2400 & 2400 & 2400 & 3600 & 2400 & 2400 & 2400 & 3600 & 2400 \\
\hline R-03 & 2000 & 8000 & 6000 & 4000 & 4000 & 4000 & 4000 & 6000 & 4000 & 4000 & 4000 & 6000 & 4000 \\
\hline R-04 & 2500 & 10000 & 7500 & 5000 & 5000 & 5000 & 5000 & 7500 & 5000 & 5000 & 5000 & 7500 & 5000 \\
\hline R-05 & 3000 & 12000 & 9000 & 6000 & 6000 & 6000 & 6000 & 9000 & 6000 & 6000 & 6000 & 9000 & 6000 \\
\hline R-06 & 3000 & 12000 & 9000 & 6000 & 6000 & 6000 & 6000 & 9000 & 6000 & 6000 & 6000 & 9000 & 6000 \\
\hline R-07 & 2000 & 8000 & 6000 & 4000 & 4000 & 4000 & 4000 & 6000 & 4000 & 4000 & 4000 & 6000 & 4000 \\
\hline R-08 & 630 & 2520 & 1890 & 1260 & 1260 & 1260 & 1260 & 1890 & 1260 & 1260 & 1260 & 1890 & 1260 \\
\hline R-09 & 1000 & 4000 & 3000 & 2000 & 2000 & 2000 & 2000 & 3000 & 2000 & 2000 & 2000 & 3000 & 2000 \\
\hline R-10 & 2000 & 8000 & 6000 & 4000 & 4000 & 4000 & 4000 & 6000 & 4000 & 4000 & 4000 & 6000 & 4000 \\
\hline R-11 & 2500 & 10000 & 7500 & 5000 & 5000 & 5000 & 5000 & 7500 & 5000 & 5000 & 5000 & 7500 & 5000 \\
\hline R-12 & 3000 & 12000 & 9000 & 6000 & 6000 & 6000 & 6000 & 9000 & 6000 & 6000 & 6000 & 9000 & 6000 \\
\hline
\end{tabular}

Table- 5: Waste water(Liters) which can be reused for further washing:

\begin{tabular}{|l|l|l|l|l|l|l|l|l|l|l|l|l|l|}
\hline $\begin{array}{l}\text { React } \\
\text {-ors }\end{array}$ & $\begin{array}{l}\text { Size of } \\
\text { Reactor } \\
\text { in [Lit] }\end{array}$ & a & b & c & d & e & f & G & h & i & j & K & l \\
\hline $\begin{array}{l}\text { No of Washes } \\
\text { Reused }\end{array}$ & 3 & 2 & 1 & 1 & 1 & 1 & 2 & 2 & 2 & 1 & 2 & 1 \\
\hline R-01 & 750 & 2250 & 1500 & 750 & 750 & 750 & 750 & 1500 & 1500 & 1500 & 750 & 1500 & 750 \\
\hline
\end{tabular}




\begin{tabular}{|l|l|l|l|l|l|l|l|l|l|l|l|l|l|} 
R-02 & 1200 & 3600 & 2400 & 1200 & 1200 & 1200 & 1200 & 2400 & 2400 & 2400 & 1200 & 2400 & 1200 \\
\hline R-03 & 2000 & 6000 & 4000 & 2000 & 2000 & 2000 & 2000 & 4000 & 4000 & 4000 & 2000 & 4000 & 2000 \\
\hline R-04 & 2500 & 7500 & 5000 & 2500 & 2500 & 2500 & 2500 & 5000 & 5000 & 5000 & 2500 & 5000 & 2500 \\
\hline R-05 & 3000 & 9000 & 6000 & 3000 & 3000 & 3000 & 3000 & 6000 & 6000 & 6000 & 3000 & 6000 & 3000 \\
\hline R-06 & 3000 & 9000 & 6000 & 3000 & 3000 & 3000 & 3000 & 6000 & 6000 & 6000 & 3000 & 6000 & 3000 \\
\hline R-07 & 2000 & 6000 & 4000 & 2000 & 2000 & 2000 & 2000 & 4000 & 4000 & 4000 & 2000 & 4000 & 2000 \\
\hline R-08 & 630 & 1890 & 1260 & 630 & 630 & 630 & 630 & 1260 & 1260 & 1260 & 630 & 1260 & 630 \\
\hline R-09 & 1000 & 3000 & 2000 & 1000 & 1000 & 1000 & 1000 & 2000 & 2000 & 2000 & 1000 & 2000 & 1000 \\
\hline R-10 & 2000 & 6000 & 4000 & 2000 & 2000 & 2000 & 2000 & 4000 & 4000 & 4000 & 2000 & 4000 & 2000 \\
\hline R-11 & 2500 & 7500 & 5000 & 2500 & 2500 & 2500 & 2500 & 5000 & 5000 & 5000 & 2500 & 5000 & 2500 \\
\hline R-12 & 3000 & 9000 & 6000 & 3000 & 3000 & 3000 & 3000 & 6000 & 6000 & 6000 & 3000 & 6000 & 3000 \\
\hline
\end{tabular}

\section{PROBLEM SOLUTION}

The main objectives of the problem are to develop a mathematical program to optimize the no of batches of product produced, minimize the waste water generation by optimizing the maximum recovery of water which can reduce the usage of fresh water. Hence, it can reduce the production cost and increase the profitability

Four objectives equation considered separately are

$$
\begin{aligned}
\text { Zprod } & =\Sigma((\mathrm{i}, \mathrm{j}), \mathrm{x}(\mathrm{j})) \\
\text { Zprofit } & =\Sigma((\mathrm{i}, \mathrm{j}), \mathrm{f}(\mathrm{j}) * \mathrm{x}(\mathrm{j})) \\
\text { Zwaste } & =\Sigma((\mathrm{i}, \mathrm{j}), \mathrm{d}(\mathrm{I}, \mathrm{j}) * \mathrm{x}(\mathrm{j})) \\
\text { Zrecycle } & =\Sigma((\mathrm{i}, \mathrm{j}), \mathrm{e}(\mathrm{I}, \mathrm{j}) * \mathrm{x}(\mathrm{j}))
\end{aligned}
$$

With 144 decision variables $\mathrm{X}(\mathrm{i}, \mathrm{j})$ where $\mathrm{i}$ is for reactor and there are total 12 reactors [ 1 to 12 ].

Where $\mathrm{j}$ is for product and there are total 12 products [a to j]

Six parameters considered for this program

a(i) = Total time available in hours for each reactor

$b(j)=$ Total time available in hours for each Product

$\mathrm{c}(\mathrm{j})=$ Batch size in $\mathrm{kg}$ for each product $d(i, j)=$ Fresh water required for washing each reactor to each

product

$e(i, j)=$ Recycle water collected after washing each reactor to

each product

$g(i, j)=$ Waste water generated after washing each reactor to each product

$f(j)=$ Profit in Rs. per batch for each product

\section{CONSTRAINTS}

Available time of each reactor, Batch Size of Each product, No of batches of each product, Minimum production of each product and waste generation through successive washing of each reactor has been considered to solve the given model Constraints Equations

$$
\begin{array}{lll}
- & \text { Waste as a } \lim & \Sigma((\mathrm{i}, \mathrm{j}), \mathrm{d}(\mathrm{i}, \mathrm{j}) * \mathrm{x}(\mathrm{i}, \mathrm{j})) / 90<=19000 \\
- & \text { Reactors Time } & \Sigma(\mathrm{j}, \mathrm{c}(\mathrm{j}) * \mathrm{x}(\mathrm{i}, \mathrm{j})) \quad<=\mathrm{a}(\mathrm{i}) \\
- & \text { Batch length } & \Sigma(\mathrm{i}, \mathrm{c}(\mathrm{j}) * \mathrm{x}(\mathrm{i}, \mathrm{j})) \quad<=\mathrm{b}(\mathrm{j})
\end{array}
$$

\section{RESULTS \& DISCUSSION}

The results of this case study is obtained using GAMS 24.1 .1 on a $2.4 \mathrm{GHz}$. The computational results for this problem are compared with actual data of the company on quarterly basis.

Table- 6: Objective value

\begin{tabular}{|l|l|}
\hline Optimized No of Batches produced & 165 \\
\hline Waste water Generated & 1701.7 kilo liters \\
\hline $\begin{array}{l}\text { Optimum Amount of water } \\
\text { Recycled }\end{array}$ & 7.737 kilo liters \\
\hline Maximized Profit & Rs. 58.02/-Lakhs \\
\hline
\end{tabular}


Table- 7: GAMS result of no of batches produced for product and reactor wise

\begin{tabular}{|l|l|l|l|l|l|l|l|l|l|l|l|l|l|}
\hline Reactors & $\mathrm{a}$ & $\mathrm{b}$ & $\mathrm{c}$ & $\mathrm{d}$ & $\mathrm{E}$ & $\mathrm{f}$ & $\mathrm{g}$ & $\mathrm{h}$ & $\mathrm{i}$ & $\mathrm{j}$ & $\mathrm{k}$ & $\mathrm{l}$ & Reactor \\
\hline 1 & $\mathrm{l}$ & & & & 5 & & & & & 5 & 2 & & 13 \\
\hline 2 & & 15 & & & & & & & & & & & 15 \\
\hline 3 & 1 & 15 & & & & & & & & & & & 16 \\
\hline 4 & 7 & & & & & & & & & & & & 7 \\
\hline 5 & 5 & & 1 & 4 & & 2 & 5 & 5 & & & & & 22 \\
\hline 6 & 7 & & & 6 & & 6 & & & & & & & 19 \\
\hline 7 & 1 & 11 & & & & & & & & & & & 12 \\
\hline 8 & & 1 & & & 5 & & & & & & & 4 & 10 \\
\hline 9 & 4 & 5 & & & & & & & & & & & 9 \\
\hline 10 & 9 & & & & & & & & & & & & 9 \\
\hline 11 & 6 & & 1 & & & 6 & & & 5 & & & & 18 \\
\hline 12 & 41 & 60 & 4 & 10 & 10 & 14 & 5 & 5 & 5 & 5 & 2 & 4 & 165 \\
\hline $\begin{array}{l}\text { Total notches } \\
\text { Bats }\end{array}$ & & & & & & & & & & & & & 15 \\
\hline
\end{tabular}

Table- 8: Actual result of no of batches produced for product and reactor wise

\begin{tabular}{|l|l|l|l|l|l|l|l|l|l|l|l|l|l|}
\hline Reactors & $\mathrm{a}$ & $\mathrm{b}$ & $\mathrm{c}$ & $\mathrm{d}$ & $\mathrm{E}$ & $\mathrm{f}$ & $\mathrm{g}$ & $\mathrm{h}$ & $\mathrm{i}$ & $\mathrm{j}$ & $\mathrm{k}$ & $\mathrm{l}$ & Reactor \\
\hline $\mathbf{1}$ & & & 4 & & & & & 3 & & & & & 7 \\
\hline $\mathbf{2}$ & & 13 & & & & & & & & & & & 13 \\
\hline $\mathbf{3}$ & 5 & 7 & & & & 1 & & 1 & & & & & 14 \\
\hline $\mathbf{5}$ & 3 & 3 & & & 5 & 1 & & & & & & & 12 \\
\hline $\mathbf{6}$ & 5 & 3 & & & & & & & & & & & 8 \\
\hline $\mathbf{7}$ & 4 & 2 & & & 4 & 3 & 2 & & 2 & & & & 17 \\
\hline $\mathbf{8}$ & 6 & 2 & & & & & 1 & & & 3 & & & 12 \\
\hline $\mathbf{9}$ & 13 & & 5 & & & & & & & & & 18 \\
\hline $\mathbf{1 0}$ & 4 & & & & & 2 & & & 3 & & 2 & & 11 \\
\hline $\mathbf{1 1}$ & 6 & & & & & & & & & 1 & & 2 & 9 \\
\hline $\mathbf{1 2}$ & 5 & & & & & & & & & & & 2 & 7 \\
\hline $\begin{array}{l}\text { Total } \\
\text { Batches }\end{array}$ & 38 & 54 & 4 & 9 & 9 & 11 & 3 & 4 & 5 & 4 & 2 & 4 & 147 \\
\hline
\end{tabular}

The results shown in Table- 7 are the optimized no of batches that can be produced for the given data and actual constraint. These results are compared with the actual production of the plant which is available in Table- 8. Hence, GAMS data suggests that for the same set of data 18 additional batches can be produced.

Table- 9: Comparison of GAMS Data v/s Actual Data Product wise

\begin{tabular}{|l|lr|l|}
\hline Type of Product & $\begin{array}{l}\text { Actual Data } \\
\text { (number } \\
\text { batches) }\end{array}$ & $\begin{array}{l}\text { GAMS Data } \\
\text { (number of batches) }\end{array}$ \\
\hline A & 38 & 41 \\
\hline B & 54 & 60 \\
\hline C & 4 & 4 \\
\hline
\end{tabular}




\begin{tabular}{|l|l|l|} 
D & 9 & 10 \\
\hline E & 9 & 10 \\
\hline F & 11 & 14 \\
\hline G & 3 & 5 \\
\hline H & 4 & 5 \\
\hline I & 5 & 5 \\
\hline J & 4 & 5 \\
\hline K & 2 & 2 \\
\hline L & 4 & 4 \\
\hline Total & 147 & 165 \\
\hline
\end{tabular}

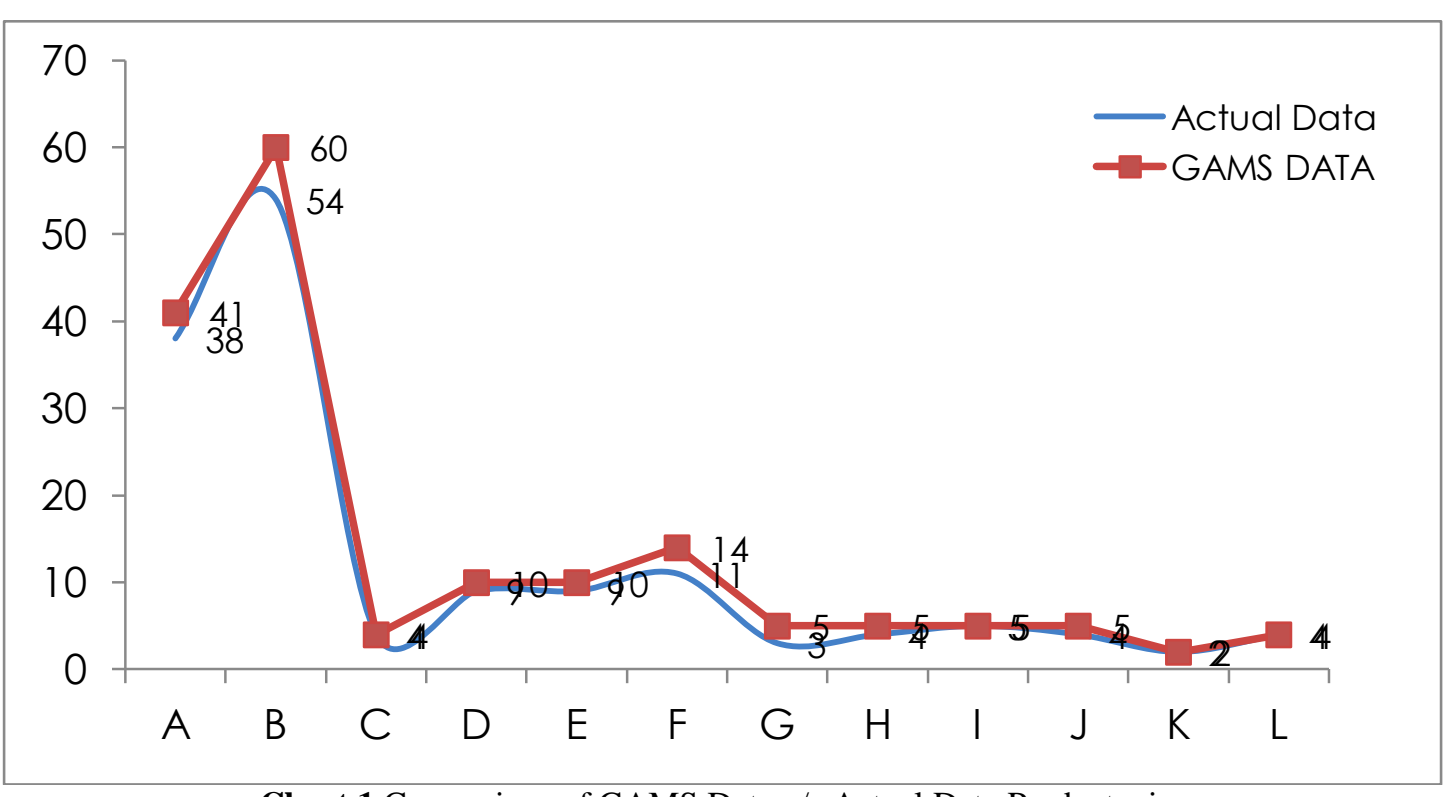

Chart 1 Comparison of GAMS Data v/s Actual Data Product wise

The GAMS data is compared with actual data on the basis of batches produced of each product the result is shown in Table- 9 and the same has been presented in Chart1. This suggests that the batches of most of the product can be optimized compared to actual production.

Table- 10: Comparison of GAMS Data v/s Actual Data Reactor wise

\begin{tabular}{|l|l|l|}
\hline Reactor No & $\begin{array}{l}\text { Actual Data } \\
\text { (number of } \\
\text { batches) }\end{array}$ & $\begin{array}{l}\text { GAMS Data } \\
\text { (number of } \\
\text { batches) }\end{array}$ \\
\hline 1 & 9 & 13 \\
\hline 2 & 12 & 14 \\
\hline 3 & 13 & 16 \\
\hline 4 & 12 & 11 \\
\hline 5 & 20 & 24 \\
\hline 6 & 23 & 26 \\
\hline 7 & 10 & 9 \\
\hline 8 & 9 & 10 \\
\hline 9 & 10 & 11 \\
\hline 10 & 8 & 7 \\
\hline 11 & 9 & 9 \\
\hline 12 & 12 & 15 \\
\hline Total & 147 & 165 \\
\hline
\end{tabular}


The GAMS data is compared with actual data on the basis no of batches produced in each reactor the result is shown in Table-10 and has been presented in Chart 2. This suggests that the batches of most of the product can be optimized compare to actual production which is possible because it takes the optimum occupancy of most of reactors.

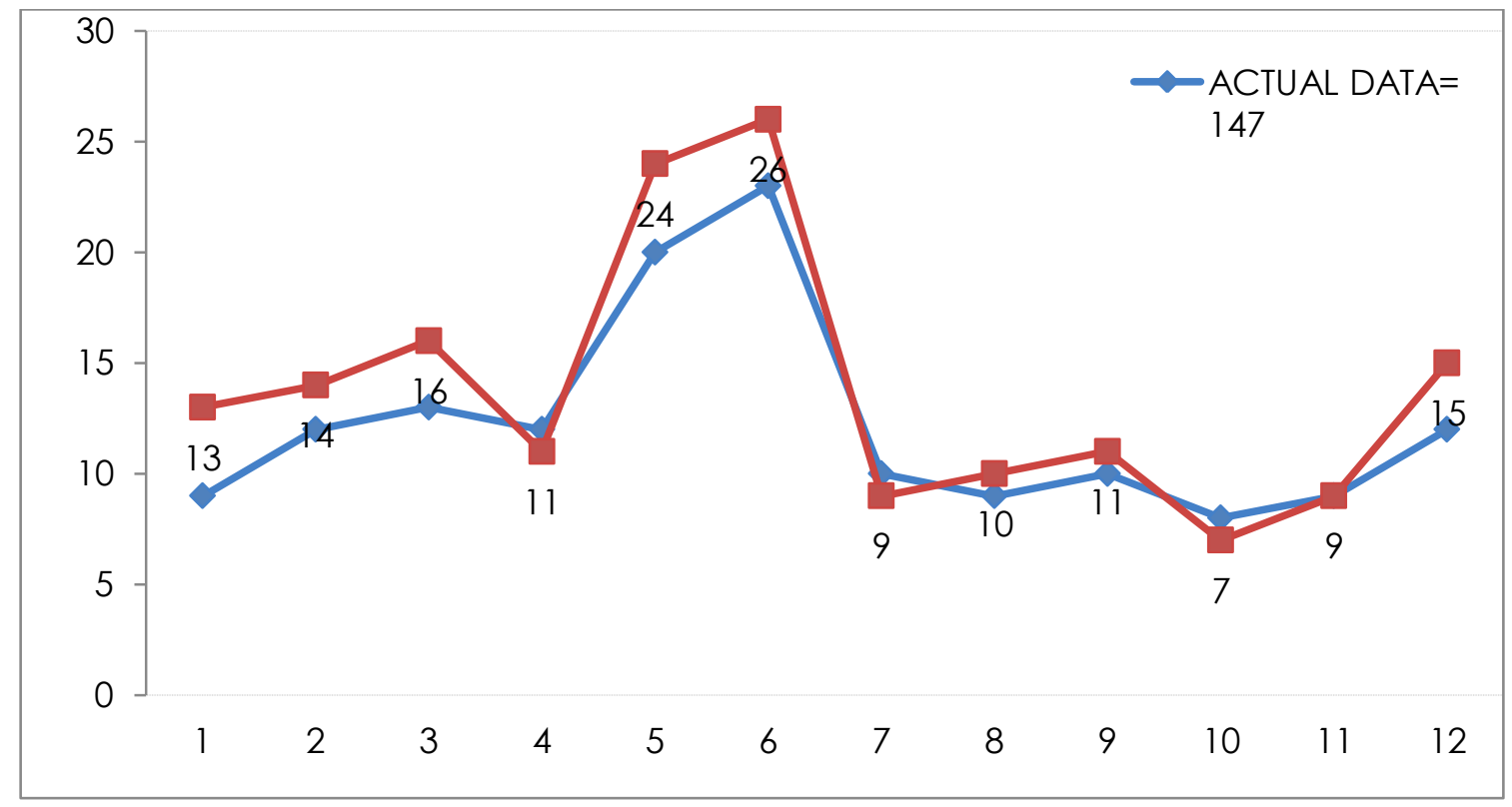

Chart 2 Comparison of GAMS Data v/s Actual Data Reactor wise

Table- 11: Flexibility of GAMS Program for future planning

\begin{tabular}{|l|l|l|l|l|}
\hline Sr.No & $\begin{array}{l}\text { Total waste } \\
\text { water } \quad \begin{array}{l}\text { No } \\
\text { day) as a } \\
\text { limit in liters }\end{array}\end{array}$ & $\begin{array}{l}\text { Batches } \\
\text { water in liters }\end{array}$ & $\begin{array}{l}\text { Profit in lac of } \\
\text { Rs. }\end{array}$ \\
\hline 1 & 19000 & 165 & 7737 & 58 \\
\hline 2 & 17000 & 160 & 7292 & 55.6 \\
\hline 3 & 15000 & 126 & 6605 & 40.9 \\
\hline 4 & 12000 & 92 & 5412 & 31 \\
\hline 5 & 10000 & 64 & 4626 & 21.4 \\
\hline 6 & 8000 & 60 & 3778 & 19.7 \\
\hline 7 & 5000 & 47 & 2492 & 17.02 \\
\hline
\end{tabular}

The GAMS program offers so much flexibility for future planning. The no of batches of each product produced is optimized by considering the total waste on daily basis as a major constraint. Total waste water generated and recycle water for further use is calculated. The profitability is also calculated by considering the fresh water cost.

Table- 12: Summary of optimized results

\begin{tabular}{|l|l|l|l|}
\hline & GAMS Result & Actual Data & Benefit \\
\hline No of Batches & 165 & 147 & $12.24 \%$ Increase \\
\hline $\begin{array}{l}\text { Waste water Generated } \\
{[\text { liters] }}\end{array}$ & 10,02000 & $14,94,500$ & $32.95 \%$ Decrease \\
\hline $\begin{array}{l}\text { Fresh Water Reduction } \\
{[\text { liters] }}\end{array}$ & 1013670 & 1698300 & $40.31 \%$ Decrease \\
\hline Profitability [Rs.] & $58,02,000 /-$ & $51,18,000 /-$ & $13.36 \%$ Increase \\
\hline $\begin{array}{l}\text { Profitability considering } \\
\text { fresh water cost [Rs.] }\end{array}$ & $64,98,330 /-$ & $53,21,800 /-$ & $22.10 \%$ Increase \\
\hline
\end{tabular}


The overall comparative study has been carried out for GAMS results with actual plant data and same is summarized in Table12.. This indicates that the GAMS results have shown significant benefit in all the aspects like production, waste water generation, fresh water requirement and in terms of profitability.

\section{AREA \& SPACE REQUIREMENT OF HOLDING TANKS}

The major part of waste is generated through washing of reactors carried out after the changeover of batch products. This waste is further categorized as high COD waste which is directed to ETP plant and low COD waste water which can be recycled and re used for the next washing cycle. The two cases have been considered either to have individual holding tank along with each reactor or to have two bigger centralized holding tank which can take care of high and low COD water of entire 12 reactors.

Table- 13: Area \& Space Requirement for Re-Cycle ( Low COD) Water Tank

\begin{tabular}{|l|l|l|l|l|l|l|}
\hline & $\begin{array}{l}\text { Re-cycle } \\
\text { water in liters }\end{array}$ & $\begin{array}{l}\text { Net } \\
\text { capacity in } \\
\text { liters }\end{array}$ & $\begin{array}{l}\text { Overall height } \\
\text { in }(\mathrm{mm})\end{array}$ & $\begin{array}{l}\text { Overall diameter } \\
\text { in }(\mathrm{mm})\end{array}$ & $\begin{array}{l}\text { Area of storage } \\
\text { tank base Area= } \\
\pi r^{2}\left(\mathrm{~m}^{2}\right)\end{array}$ & $\begin{array}{l}\text { Cost of frp } \\
\text { tank in Rs. }\end{array}$ \\
\hline R-01 & 1688 & 2000 & 1630 & 1370 & 1.47 & 45000 \\
\hline R-02 & 2700 & 3000 & 1860 & 1530 & 1.84 & 65000 \\
\hline R-03 & 4500 & 5000 & 2050 & 1900 & 2.83 & 100000 \\
\hline R-04 & 5625 & 6000 & 2250 & 1950 & 2.98 & 120000 \\
\hline R-05 & 6750 & 7000 & 2400 & 2050 & 3.30 & 140000 \\
\hline R-06 & 6750 & 7000 & 2400 & 2050 & 3.30 & 140000 \\
\hline R-07 & 4500 & 5000 & 2050 & 1900 & 2.83 & 100000 \\
\hline R-08 & 1418 & 1500 & 1350 & 1235 & 1.20 & 35000 \\
\hline R-09 & 2250 & 2500 & 1650 & 1500 & 1.77 & 55000 \\
\hline R-10 & 4500 & 5000 & 2050 & 1900 & 2.83 & 100000 \\
\hline R-11 & 5625 & 6000 & 2250 & 1950 & 2.98 & 115000 \\
\hline R-12 & 6750 & 7000 & 2400 & 2050 & 3.30 & 135000 \\
\hline & & & & $(30.64) \mathrm{m}^{2}$ & & 1150000 \\
\hline TOTAL & 53055 & 60000 & 4875 & 4250 & $14.18 \mathrm{~m}^{2}$ & 800000 \\
\hline
\end{tabular}

Table- 14: Area \& Space Requirement for Waste (High COD) Water Tank

\begin{tabular}{|l|l|l|l|l|l|l|}
\hline Rector & High COD & $\begin{array}{l}\text { Net capacity } \\
{[\text { liters }]}\end{array}$ & $\begin{array}{l}\text { Overall ht. In } \\
(\mathrm{mm})\end{array}$ & $\begin{array}{l}\text { Overall dia. } \\
\text { in }(\mathrm{mm})\end{array}$ & $\begin{array}{l}\text { Base } \\
A=\pi r^{2}\left(\mathrm{~m}^{2}\right)\end{array}$ & $\begin{array}{l}\text { Cost of FRP tank } \\
\text { in Rs. }\end{array}$ \\
\hline R-01 & 2250 & 2500 & 1650 & 1500 & 1.77 & 55000 \\
\hline R-02 & 3600 & 4000 & 1870 & 1720 & 2.32 & 85000 \\
\hline R-03 & 6000 & 7000 & 2400 & 2050 & 3.30 & 135000 \\
\hline R-04 & 7500 & 8000 & 2500 & 2150 & 3.62 & 150000 \\
\hline R-05 & 9000 & 10000 & 2700 & 2300 & 4.15 & 190000 \\
\hline R-06 & 9000 & 10000 & 2700 & 2300 & 4.15 & 190000 \\
\hline R-07 & 6000 & 7000 & 2400 & 2050 & 3.30 & 135000 \\
\hline R-08 & 1890 & 2000 & 1630 & 1370 & 1.47 & 45000 \\
\hline R-09 & 3000 & 3500 & 1800 & 1650 & 2.14 & 75000 \\
\hline R-10 & 6000 & 7000 & 2400 & 2050 & 3.30 & 135000 \\
\hline R-11 & 7500 & 8000 & 2500 & 2150 & 3.62 & 150000 \\
\hline R-12 & 9000 & 10000 & 2700 & 2300 & 4.15 & 190000 \\
\hline & & & & & $17.29) \mathrm{m}^{2}$ & 1535000 \\
\hline TOTAL & 70740 & 800000 & 5300 & 4700 & $17.34 \mathrm{~m}^{2}$ & 1100000 \\
\hline
\end{tabular}

The comparative study has been considered whether to have individual tanks of low COD and high COD nearer to each reactor or to have two centralized tanks one for each low and high COD, which should take care of all twelve reactors waste water. Area \& Space Requirement for low and high COD tanks for both the cases is calculated and same is presented in Table- 13 and 14. If we combine the results presented in Table- 13 and 14, the total area required for the centralized tanks (High COD tank 17.35 +Low COD tank $14.18)$ is $31.5 \mathrm{~m}^{2}$ whereas the total area required for individual tanks(High COD tank37.29 +Low COD tank $30.64)$ is $68 \mathrm{~m}^{2}$ which is almost $53 \%$ less. The total cost required for centralized tank(High COD tank Rs.11 lakh+ +Low COD tank Rs.8 lakh) is Rs.19 lakh which is almost $30 \%$ less than the cost required for individual tanks (High COD tank Rs.15.35 lakh+ +Low COD tank Rs.11 lakh) Both comparisons clearly indicate that centralized tank is much better than the individual tank in terms of area and cost 


\section{CONCLUSION}

In this case study the product optimization of multiproduct pharmaceutical plant having 12 different products and 12 reactors of different size is done successfully by using MINLP formulation and commercial solver GAMS 24.1.1 .This study shows that the no. of batches within the same source of available resources can be increased by $12.24 \%$ and the profitability can be increased to $13.36 \%$. On the other hand waste generation is reduced to almost $33 \%$ because of recycle and re-use opportunities. The fresh water intake can be reduced to $40 \%$ which would also help to increase profitability by $22 \%$. The comparative study of holding tanks has shown that the centralized (bigger) tanks of each low as well high COD occupies $50 \%$ of area compared to individual holding tanks and even cost wise also the centralize tanks are $29 \%$ cheaper than individual holding tanks.

\section{REFERENCES:}

[1] Seid, R., Majozi, Optimization of energy and water use in multipurpose batch plants using an improved mathematical formulation. Chemical Engineering Science, 2014 - Elsevier

[2] Esmael R. Seid $\uparrow$ and Thokozani Majozi Design and Synthesis of Multipurpose Batch Plants Using a Robust Scheduling Platform. Ind. Eng. Chem. Res., 2013, 52 (46), pp 16301-16313

[3] R. Parand, H. M. Yao, M. O. Tadé, and V. Pareek. Composite Table- Algorithm - A Powerful Hybrid Pinch Targeting Method for Various Problems in Water Integration. International Journal of Chemical Engineering and Applications, Vol. 4, No. 4, August 2013

[4] Bhanu Prasad Behera, Dr. Rati Ranjan Dash, Dr.Arun kumar Panda3.Evaluation of Minimum Makespan using Modified Evolutionary Algorithm
Journal of Engineering Innovation and Research Volume: IV, Issue: 1

[5] Adekola, Stamp, J. D., Majozi, T. Simultaneous Optimization of Energy and Water in Multipurpose Batch Plants, computers in operations and information processing.

[6] Marianthi Ierapetritou. Modeling and Managing Uncertainty in Process Planning and Scheduling. Springer Optimization and Its Applications 30, DOI 10.1007/978-0-387-88617-63

[7] Jaime Cerdá Cerda Dynamic scheduling in multiproduct batch plants Computers \& Chemical Engineering. Volume 27, Issues 8-9, 15 September 2003, Pages 1247-1259

[8] P. Oliver',R. Rodríguez, S. Udaquiola Water use optimization in batch process industries. Design of the water network Journal of Cleaner Production Dec.2008 1275-1286

[9] Majozi, T., Gouws, J.F., A mathematical optimization approach for wastewater minimization in multipurpose batch plants: Multiple contaminants. Comp. Chem. Eng. 33, 1826-1840. 2009.

[10] Zukui Li, Marianthi Ierapetritou Process scheduling under uncertainty: Review and challenges. Computers \& Chemical Engineering, vol. 32, no. 45, pp. 715-727, 2008

[11] Méndez, C.A., Cerdá, J., Grossmann, I.E., Harjunkoski, I., Fahl, M., 2006. State of- the- art review of optimization methods for short-term scheduling of batch processes. Comput. Chem. Eng. 30, 913-946.

[12] Majozi, T., Gouws, J.F., 2009. A mathematical optimization approach for wastewater minimization in multipurpose batch plants: Multiple contaminants. Comp. Chem. Eng. 33, 1826-1840.

[13] Seid, R., Majozi, T., 2012. A robust mathematical formulation for multipurpose batch plants. Chem. Eng. Sci. 68, 36-53.

\section{ANNEXURE}

\section{GAMS CODE:}

set i /1,2,3,4,5,6,7,8,9,10,11,12/

$\mathrm{j} / \mathrm{a}, \mathrm{b}, \mathrm{c}, \mathrm{d}, \mathrm{e}, \mathrm{f}, \mathrm{g}, \mathrm{h}, \mathrm{i}, \mathrm{j}, \mathrm{k}, \mathrm{l} /$;

Parameters

a(i) /1 980, 2 1800, 3 1980, 4 1300, 5 1690, 6 1600, 7 1550, 8 1850, 9 1740, 10 1320, 11 1620,12 1620/

b(j) / a 7380, b 7200, c 280, d 300, e 1000, f 280, g 250, h 300, i 350, j 100, k 150, 1 1000/

c(j) / a 180, b 120, c 70, d 30, e 100, f 20, g 50, h 60, i 70, j 20, k 75, 1250 /

f(j) / a 23000, b 30000, c 45000, d 35000, e 40000, f 45000, g 60000, h 60000, i 70000, j 45000, k 42000, 1 60000/;

Table d(i,j) : Fresh water required (liters) for washing each reactor to each product

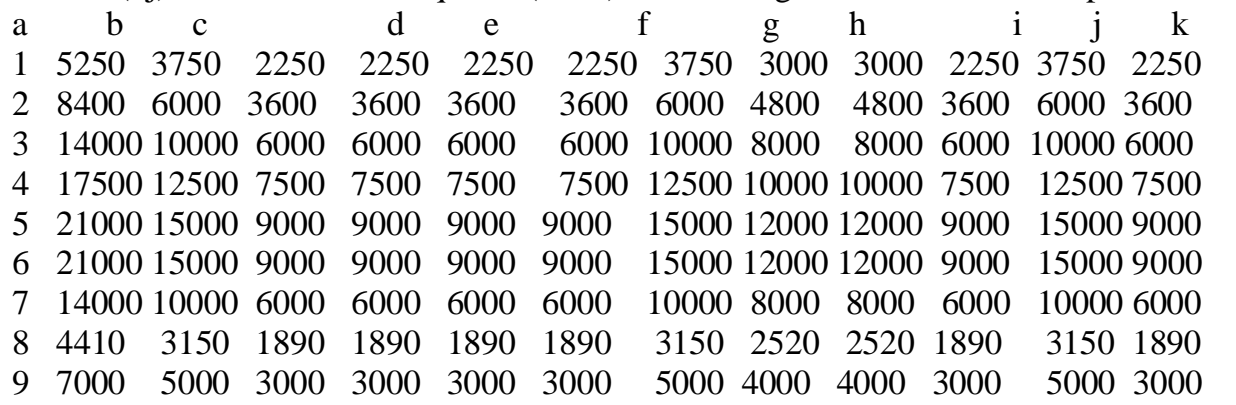




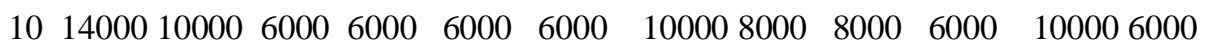

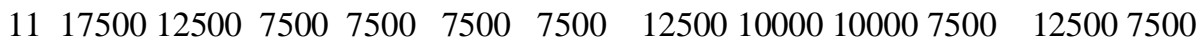

$1221000150009000900090009000 \quad 1500012000120009000150009000$

Table E(i,j): Recycle water (liters) collected after washing each reactor to each product

\begin{tabular}{|c|c|c|c|c|c|c|c|c|c|c|c|c|c|}
\hline $\mathrm{a}$ & & $\mathrm{b}$ & $\mathrm{c}$ & d & & $\mathrm{e}$ & $\mathrm{f}$ & $\mathrm{g}$ & $\mathrm{h}$ & $\mathrm{i}$ & $\mathrm{j}$ & $\mathrm{k}$ & 1 \\
\hline 1 & 2250 & 1500 & 750 & 75 & & 750 & 750 & 1500 & 1500 & 3000 & 3000 & 6000 & 750 \\
\hline 2 & 3600 & 2400 & 1200 & 1200 & 1200 & 1200 & 2400 & 2400 & 2400 & 1200 & 2400 & 1200 & \\
\hline 3 & 6000 & 4000 & 2000 & 2000 & 2000 & 2000 & 4000 & 4000 & 4000 & 2000 & 4000 & 2000 & \\
\hline 4 & 7500 & 5000 & 2500 & 2500 & 2500 & 2500 & 5000 & 5000 & 5000 & 2500 & 5000 & 2500 & \\
\hline 5 & 9000 & 6000 & 3000 & 3000 & 3000 & 3000 & 6000 & 6000 & 6000 & 3000 & 6000 & 3000 & \\
\hline 6 & 9000 & 6000 & 3000 & 3000 & 3000 & 3000 & 6000 & 6000 & 6000 & 3000 & 6000 & 3000 & \\
\hline 7 & 6000 & 4000 & 2000 & 2000 & 2000 & 2000 & 4000 & 4000 & 4000 & 2000 & 4000 & 2000 & \\
\hline 8 & 1890 & 1260 & 630 & 630 & 630 & 630 & 1260 & 1260 & 1260 & 630 & 1260 & 630 & \\
\hline 9 & 3000 & 2000 & 1000 & 1000 & 1000 & 1000 & 2000 & 2000 & 2000 & 1000 & 2000 & 1000 & \\
\hline 10 & 3600 & 2400 & 1200 & 1200 & 1200 & 1200 & 2400 & 2400 & 2400 & 1200 & 2400 & 1200 & \\
\hline 11 & 7500 & 5000 & 2500 & 2500 & 2500 & 2500 & 5000 & 5000 & 5000 & 2500 & 5000 & 2500 & \\
\hline 12 & 9000 & 6000 & 3000 & 3000 & 3000 & 3000 & 6000 & 6000 & 6000 & 3000 & 6000 & 3000 & \\
\hline
\end{tabular}

Table G(i,j): Waste water (liters) generated after washing each reactor to each product

$\begin{array}{lllllllllllllllll}\mathrm{a} & \mathrm{b} & \mathrm{c} & \mathrm{d} & \mathrm{e} & \mathrm{f} & \mathrm{g} & \mathrm{h} & \mathrm{i} & \mathrm{j} & \mathrm{k} & 1\end{array}$

$\begin{array}{lllllllllllll}1 & 3000 & 2250 & 1500 & 1500 & 1500 & 1500 & 2250 & 1500 & 1500 & 1500 & 2250 & 1500\end{array}$

$248003600 \quad 2400 \quad 2400 \quad 2400 \quad 2400360024002400240036002400$

$38000 \quad 6000 \quad 4000 \quad 4000 \quad 4000 \quad 40006000 \quad 4000 \quad 4000400060004000$

$4 \quad 100007500 \quad 5000 \quad 5000 \quad 5000 \quad 50007500 \quad 5000 \quad 5000 \quad 500075005000$

$\begin{array}{lllllllllll}5 & 120009000 & 6000 & 6000 & 6000 & 6000 & 9000 & 6000 & 6000 & 60009000 & 6000\end{array}$

$6 \quad 120009000 \quad 6000 \quad 6000 \quad 6000 \quad 6000900060006000600090006000$

$7 \quad 8000 \quad 6000 \quad 4000 \quad 4000 \quad 4000 \quad 4000 \quad 60004000 \quad 4000 \quad 400060004000$

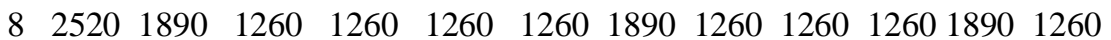

$940003000 \quad 2000 \quad 2000 \quad 20002000300020002000200030002000$

$1080006000 \quad 4000 \quad 40004000 \quad 4000600040004000400060004000$

$\begin{array}{lllllllllll}11 & 100007500 & 5000 & 5000 & 5000 & 5000 & 7500 & 5000 & 5000 & 50007500 & 5000\end{array}$

121200090006000600060006000900060006000600090006000 ;

variable $\mathrm{z}, \mathrm{z} 1, \mathrm{z} 2, \mathrm{z} 3$;

integer variable $\mathrm{x}(\mathrm{i}, \mathrm{j})$;

equations Production,Recycle,Waste,profit,a1,a2,a3,a4,a5,a6,a7,a8,a9,a10;

Production.. $\quad z=e=\operatorname{sum}((i, j), x(i, j))$;

Recycle.. $\quad z 1=e=\operatorname{sum}((i, j), E(i, j) * x(i, j)) / 90$;

Profit.. $\quad \mathrm{z} 2=e=\operatorname{sum}((\mathrm{i}, \mathrm{j}), \mathrm{f}(\mathrm{j}) * \mathrm{x}(\mathrm{i}, \mathrm{j}))$;

Waste.. $\quad z 3=e=\operatorname{sum}((i, j), G(i, j) * x(i, j)) / 90$;

a1.. $\quad \operatorname{sum}((\mathrm{i}, \mathrm{j}), \mathrm{d}(\mathrm{i}, \mathrm{j}) * x(\mathrm{i}, \mathrm{j})) / 90=\mathrm{e}=19500$;

a2(i).. $\quad \operatorname{sum}(\mathrm{j}, \mathrm{c}(\mathrm{j}) * \mathrm{x}(\mathrm{i}, \mathrm{j}))=\mathrm{L}=\mathrm{a}(\mathrm{i})$;

a4.. $\quad$ c("c")*x("1","c")=l=b("c");

a3(j).. $\quad \operatorname{sum}(i, c(j) * x(i, j))=L=b(j)$;

a5(i,"a").. $\quad x(i, " a ")=l=9$;

a6(i,"b").. $\quad x(i, " b ")=1=15$;

a7(i,"d").. $\quad x(i, " d ")=l=6$;

$\mathrm{a} 8(\mathrm{i}, \mathrm{f} ") . . \quad \mathrm{x}(\mathrm{i}, \mathrm{f}$ " $)=\mathrm{l}=6$;

a9(i,"g").. $\quad x(i, " g ")=1=8$;

a10(i,"e").. $\quad x(i, " e ")=1=5$;

Model apd /all/;

Solve apd using MINLP maximizing Z1; 